\title{
A Half-Century (1970-2020) of the Social Scientific Study of Jewry: Reflections and Projections on Past, Present, and Future
}

\section{Arnold Dashefsky ${ }^{1}$}

Accepted: 23 July 2021 / Published online: 6 September 2021

(c) The Author(s), under exclusive licence to Springer Nature B.V. 2021

\begin{abstract}
I begin with a tribute to my professors at Gratz College and Temple University in Philadelphia (1960-1966), at Hebrew University and Hayim Greenberg College in Jerusalem (1962-1963), and at the University of Minnesota in Minneapolis (19661969), as well as to my colleagues and co-authors; and I follow with five substantive points:
\end{abstract}

1. An assessment of the past versus the present of the social scientific study of Jewry is offered, for which I note that the way to understand the social and religious adjustments of American Jews is to examine their economic and political adjustments first.

2. The changes across a 50-year time span of ASSJ as a professional organization are charted and reveal that between 1970 and 2020 the organization had more than tripled in size, became much more gender-balanced, and initiated a journal (Contemporary Jewry), which published dozens of articles in the latest 3-year cycle.

3. Grounds for optimism versus pessimism in viewing the future of American Jewry are examined as follows:

(a) Antisemitism is increasing, but Jews are the most warmly regarded US religious group.

(b) Interfaith marriage continues, but a majority of children are receiving a Jewish upbringing.

(c) The religious "nones" are growing, but the great majority of them feel proud to be Jewish.

\footnotetext{
Adapted from a presentation at the Annual Meeting of the Association for Jewish Studies, December 2020. Not for reproduction, quotation, or any other use without permission of the author. I extend thanks to the following individuals for their advice and assistance: Matt Boxer, Laurence KotlerBerkowitz, Harriet Hartman, Amy Lawton, Pamela Nadell, Bruce Philips, and Ira M. Sheskin.
}

Extended author information available on the last page of the article 
(d) Geographic mobility and residential dispersion continue, but new means of internet connections are growing.

4. Recommendations for the future of the social scientific study of US Jewry are offered.

5. Recommendations for the future of ASSJ are suggested.

Finally, I end with a personal tribute to my family and finish with a quote from the Talmud. "Scholars increase peace in the world," and conclude with this praise: "To scholars and to peace!"

Keyword Antisemitism · Geographic mobility and residential dispersion · Interfaith marriage $\cdot$ Religious "nones"

\section{Introduction: Thanks to My Colleagues}

As I only have a fraction of the 50 min to which I am accustomed, I would like to begin by thanking the Board of the Association for the Social Scientific Study of Jewry (ASSJ), President Len Saxe and Vice-President Judit Liwerant, as well as the nominating committee members for presenting me with the Sklare Award. Also, I am honored to receive this Award along with Chaim Waxman, a colleague whom I have known and respected for nearly a half-century and with whom I collaborated on a publication released in 2020 .

I want to begin my brief presentation by setting the record straight: It is true that I am the only still active member of the Association for Jewish Studies (AJS) who participated in the founding of ASSJ at the annual meeting of the American Sociological Association (ASA) in 1970. In fact, I called for the creation of a formal group to be named the "Society for the Sociological Study of Jewry," or SSSJ, based on the model of the Society for the Scientific Study of Religion (SSSR). However, it is not true that I was just a college freshman! In fact, I was in my "freshman" year as an assistant professor of sociology at the University of Connecticut.

Now, if it is true that it takes a village to raise a child, then it is also true that it takes professors and mentors to produce a scholar; and I would like to take this opportunity to acknowledge them, including: at Gratz College, Shlomo Goitein, and Elsie and William Chomsky (you may know the name as pronounced, Chomsky, as in Noam Chomsky, their son), as well as in Jerusalem at the Hebrew University and Hayim Greenberg College, Yehuda Amichai and Yigael Yadin, all of whom introduced me to an appreciation of the Hebrew language as well as archaeology as keys to unlocking Jewish civilization; at Temple University, my undergraduate professors, who sparked my interest in developing a sociological imagination; and at the University of Minnesota, my graduate professors who wrote key textbooks of their day, Don Martindale on theory (1960) and Arnold Rose, together with Caroline Rose on minority groups (1965), who taught me how to apply sociological theories and methods and turn them into publishable research. 


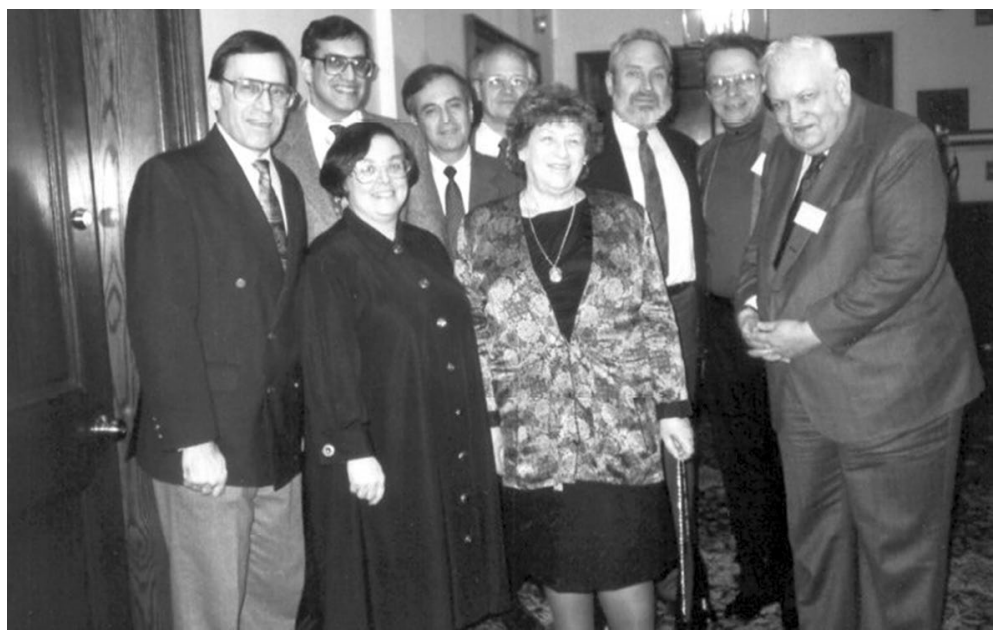

Fig. 1 Undated photo (likely December 1991). Right to left: Marshall Sklare, President, 1973-1975; Chaim Waxman, President, 1979-1981; Samuel Klausner, President, 1975-1977; Celia Heller, President, 1977-1979; Egon Mayer, President, 1983-1988; Mervin F. Verbit, President, 1971-1973; Rela Mintz Geffen, President, 1988-1990; Harold Himmelfarb, President, 1981-1983; Arnold Dashefsky, President, 1990-1996. Source: Chaim Waxman

Also, I want to acknowledge the mentorship, colleagueship, and friendship of several members and former members of AJS and ASSJ: I note with sadness that two of them, Jerry Winter and Bernie Lazerwitz (z'l), have passed away. Fortunately, I can recognize several other colleagues and friends who continue to be active in AJS, with whom I have worked recently, including Sergio DellaPergola, Harriet Hartman, Laurence Kotler-Berkowitz, and Pam Nadell, along with my coauthors, Bruce Phillips and Ira Sheskin.

Of course, I would be remiss if I did not mention the important influence of Marshall Sklare (z"l) on my intellectual development and academic accomplishments. I recall three occasions in particular. I first encountered Marshall while a student at Temple University in the 1960s. He gave a lecture, and all that I can recall about it was that there was a very large audience. Perhaps what I learned from that experience was that conducting research on the American Jewish community and lecturing about it was a legitimate academic undertaking. My second experience with Marshall was when he invited me as an untenured assistant professor to give a lecture at the Annual Meeting of the American Jewish Historical Society in May 1975 at Brandeis University, which was published later in a relatively new journal, Ethnicity (Dashefsky 1981).

A third memorable moment occurred during my presidency of ASSJ at its annual meeting, held in conjunction with the December conference of AJS, at which Marshall happily participated and posed for the attached photo (likely date of December 1991; see Fig. 1). 
Shortly thereafter, on 1 March 1992, he passed away. Subsequently, the ASSJ Board created an annual award for distinguished scholarship in his memory, which I, along with Chaim Waxman, am honored to accept today.

Lastly, I would not have been able to pursue the social scientific study of Jewry without the support of my many colleagues at the University of Connecticut, including the faculty and students of the Department of Sociology, along with the several deans, provosts, presidents, and UConn Foundation officers, who supported my work over many years; as well as the active participants of the Center for Judaic Studies and Contemporary Jewish Life at UConn who are current members of AJS, Stuart Miller, Avinoam Patt, Jeffrey Shoulson, and Sebastian Wogenstein. I would not be here today if it were not for all those whom I have mentioned and to whom I offer a heartfelt thank you!

\section{The Social Scientific Study of US Jewry: Examining Its Past and Present}

The substance of my presentation is to address the past, present, and future of the social scientific study of Jewry, spanning the half-century from 1970 until today, a time period identical to my professional activity. To do that, I will focus on the evolving experience of US Jewry as evidenced in Table 1. My AJS colleagues in the humanities hopefully will forgive me, if I rely on a table rather than a text!

In introducing Table 1, note that the far left column presents several blocks corresponding to the various time frames, their dominant themes, and associated population estimates. The top row of headers assumes that the economic and political adjustments of American Jews shape their subsequent social and religious adjustments. The first part of the table, covering the period from the origins of Jews in North America in 1654 until 1967, sets the stage for the focus on the past halfcentury. For example, in the fifth row, phase V, covering post-World War II until the Six-Day War, we may note that the US Jewish population had stabilized at 5-6 million. Antisemitism had declined from its peak in the interwar period, making it easier for Jews to move to the suburbs, replacing the urban ghettos of the early twentieth century with gilded ghettos (Kramer and Leventman 1961). Following the general post-war suburbanization movement, when many Christian neighbors joined churches, Jews followed suit by joining synagogues. While it may not sound like a sociological axiom, the Yiddish expression "vee es kristilt zikh, azoi yidilt zikh," or "what the Christians do, so do the Jews," captures the sociological insight that the behavior of minority groups follows that of the dominant group.

Turning to the more recent past, Fig. 2 appeared, as I recall, in June 1967, following Israel's victory in the Six-Day War, which led many Americans to view Jews not as victims of the Holocaust but as victors over their enemies. In a parallel way, American Jews developed a greater sense of collective pride in their Jewish identities.

This experience, coupled with the appearance of the first National Jewish Population Survey (NJPS 1971), ushered in a new phase (VI). Note in Table 1, within phases VI and VII, the third column from the left on political adjustment and 


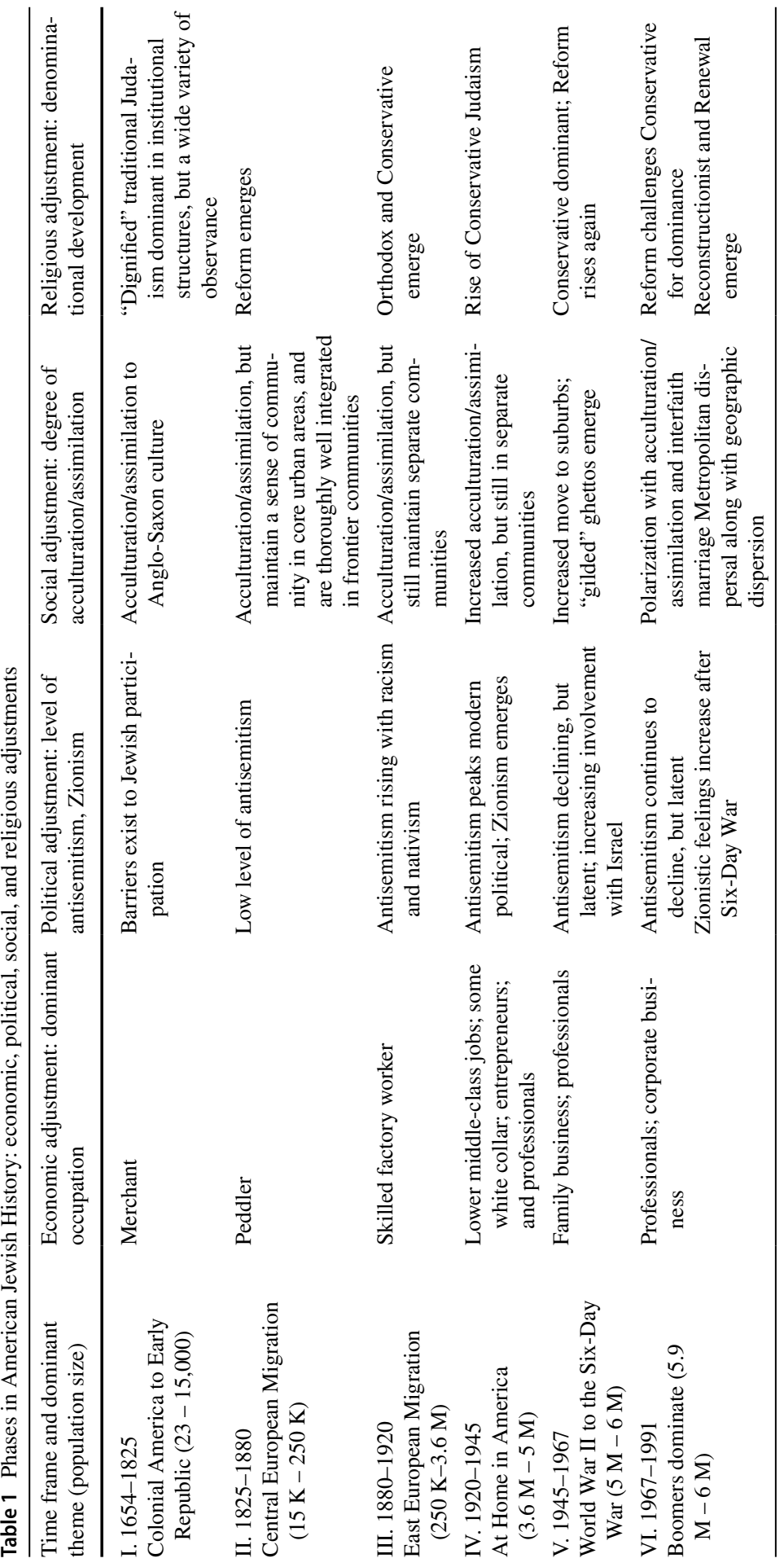




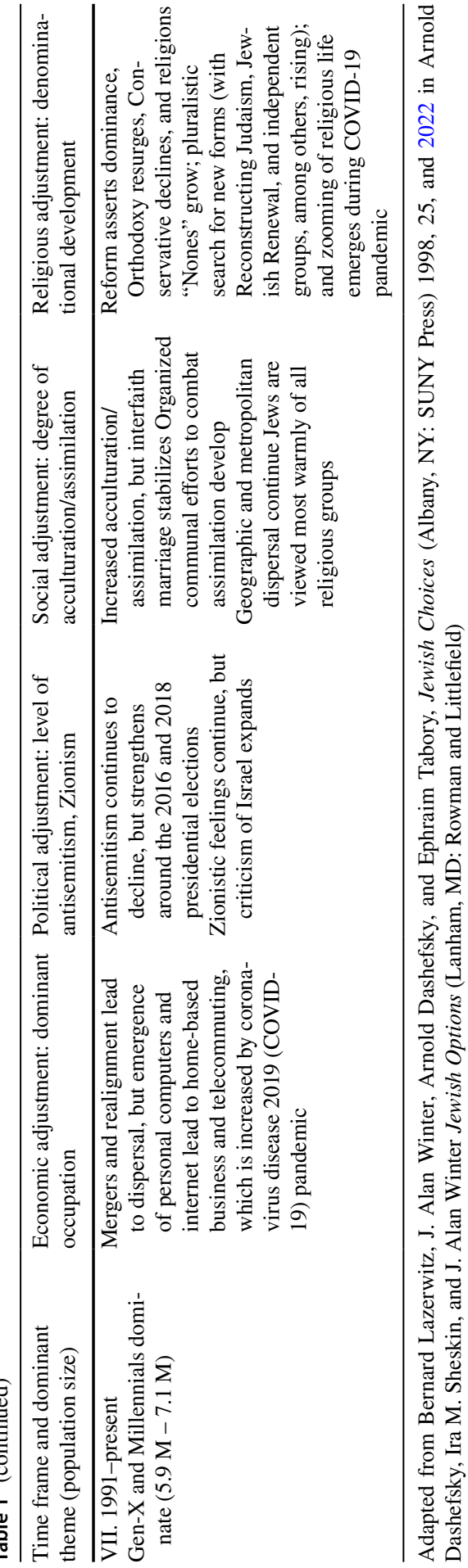




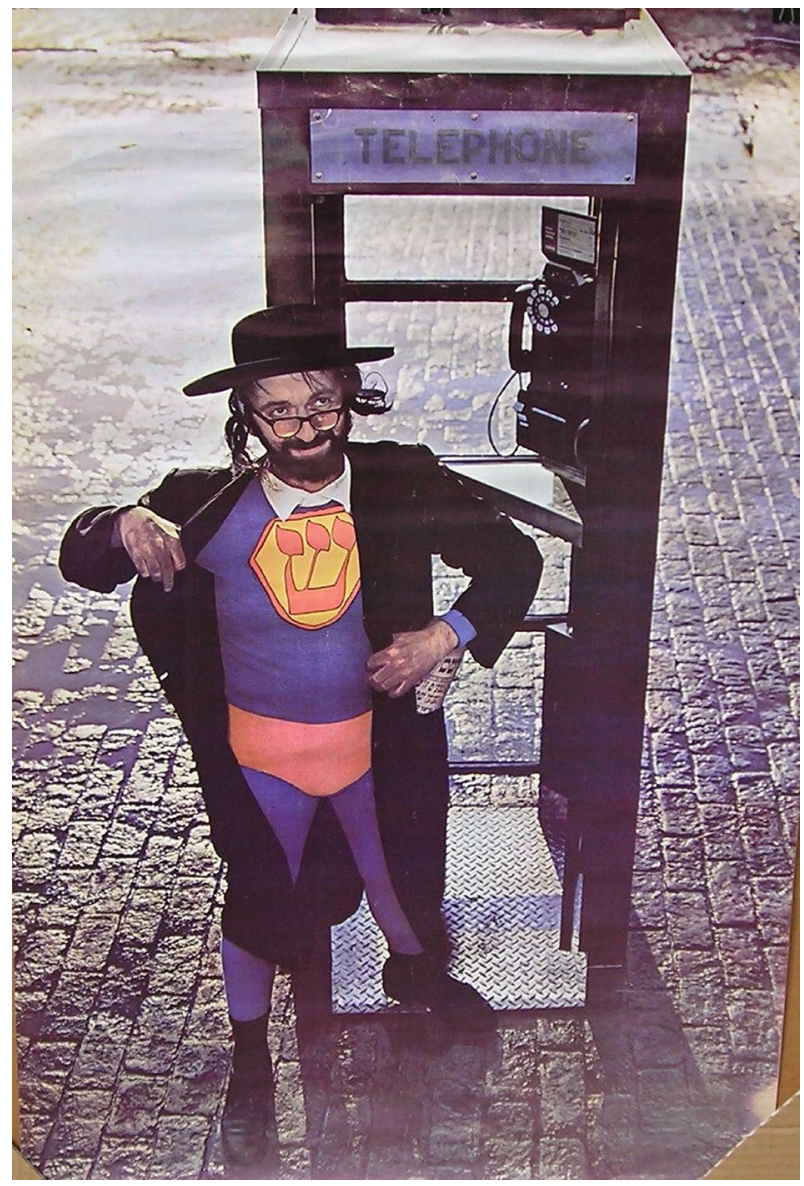

Fig. 2 "Super-Jew" cartoon embodied a new image of the Jew following the Six-Day War (June 1967)

levels of antisemitism. Through both periods, antisemitism declined from $29 \%$ (in the 1960 s) to $20 \%$ (in 1992), and in phase VII to $12 \%$ (in 2013), as measured by an 11-item scale developed by the Anti-Defamation League (ADL); but in 2016, the proportion increased slightly to $14 \%$ (Smith and Schapiro 2019). Indeed, antisemitism (both on the right and the left) has strengthened around the presidential elections of 2016 and 2020. While the most recent ADL estimate was 11\% (ADL 2020), American Jews had an increased perception of antisemitism, especially in comparison with the general public, and a greater sense of insecurity. About twice as many American Jews (37\%) see antisemitism as "a very serious problem," compared with the overall population (19\%) (American Jewish Committee 2020); and the ADL reported a substantial rise in antisemitic incidents with "more than 2100 acts of assault, vandalism, and harassment, an increase of 12 percent over the previous year. This is the highest level of antisemitic incidents since ADL's tracking began in 1979" (ADL 2020, as cited in Dashefsky and Sheskin 2021). 
Table 2 Characteristics of ASSJ: past (1970) and present (2020)

\begin{tabular}{lll}
\hline & 1970 & 2020 \\
\hline \# of attendees (1970)/members (2020) & $35^{\mathrm{a}}$ & $112^{\mathrm{b}}$ \\
Gender & Mostly males $^{\mathrm{a}}$ & About equal \\
\# of disciplines represented & $1^{\mathrm{a}}$ & $24^{\mathrm{b}}$ \\
$\begin{array}{l}\text { Contemporary Jewry }(C J) \text { journal issues over a 3-year } \\
\text { period }\end{array}$ & $5^{\mathrm{c}}$ & $11^{\mathrm{d}}$ \\
CJ \# of articles & $18^{\mathrm{c}}$ & $59^{\mathrm{d}}$ \\
\# of national studies of US Jewry & $1^{\mathrm{e}}$ & $7^{\mathrm{f}}$ \\
\# of local community studies & $38^{\mathrm{g}}$ & $266^{\mathrm{g}}$ \\
\hline
\end{tabular}

a Source: Friedman, N. 1986

${ }^{\mathrm{b}}$ Source: Boxer (2020). Personal communication

${ }^{\mathrm{c}}$ The first three issues of $C J$ in 1974 contained only letters to the editors, calls for papers, and book reviews. The first issue containing articles appeared in the fall of 1975, and the 3-year period ends in $1977 / 1978$

${ }^{\mathrm{d}}$ The most recent 3-year period of $C J$ runs from 2018 through 2020

e"Perhaps the most widely accepted prior estimate of the number of Jews by religion in America comes from the 1957 Current Population Survey, the only time in the last six decades that the U.S. Census Bureau has asked individual Americans about religious affiliation" (Pew Research Center 2013:27)

${ }^{\text {f }}$ Source: Berman Jewish DataBank holds the following: NJPS 1971, NJPS 1990, NJPS 2000-01, 2001 American Jewish Identity Survey, 2002 Survey of Heritage and Religious Identity, 2008 American Jewish Identity Survey, and Pew Research Center 2013 (Berman Jewish DataBank n.d., retrieved February 23, 2021)

${ }^{\mathrm{g}}$ Source: Berman Jewish DataBank (Retrieved February 23, 2021)

Meanwhile, in terms of social adjustments, American Jews attained prominent accomplishments in many fields: They appeared to be the most admired minority in some studies (Pew Research Center 2019), and gained more social acceptance as dramatically illustrated in the striking number of Jewish relatives of several candidates in the 2020 presidential and vice-presidential races, along with a credible run for the presidency by a Jewish candidate in the Democratic primaries.

\section{ASSJ: 1970 versus 2020}

Table 2 presents a brief overview of how the Association for the Social Scientific Study of Jewry (ASSJ) and the field to which its members are devoted has expanded. [See Friedman (1986) and Waxman (2019) for more details on the founding of ASSJ.] In 1970, the founders consisted of a largely male group of about three dozen sociologists attending the annual meeting of the American Sociological Association (ASA) in Washington, DC. As of December 2020, there were 112 members, virtually equally divided by males and females, representing at least 24 disciplines.

When ASSJ began, there was no immediate effort to create a journal. Ultimately, in 1974, the journal Contemporary Jewry was founded, but the first three issues contained only letters to the editor, calls for papers, and book reviews. The first volume containing articles appeared in fall 1975. During the subsequent 3-year period, 
running to $1977 / 1978$, only 18 articles were published. In the most recent 3 -year cycle of CJ (2018-2020), 59 articles were published on a diverse set of subjects.

In 1970, only one national probability study of American Jews existed, which was conducted in 1957 by the US Census as part of a sample survey of the religious preferences of Americans, the only time a question on religion was asked by the US Census. Another national probability study, the 1971 NJPS, the first such probability sample gathered by the then Council of Jewish Federations (now known as the Jewish Federations of North America), was in progress and subsequently reported a Jewish population of 5.4 million.

Since that time, two more such Federation-sponsored national surveys were executed: the NJPS 1990 and NJPS 2000-01, both of which reported similar numbers for the US Jewish population (5.2-5.5 million). While we wait for the Pew Research Center to publicize its 2020 survey of American Jews, we may rely on its earlier 2013 estimate of 6.7 million. ${ }^{1}$ Just as we have seen since 1970 a growth in the number of national surveys, so too there has been a growth in the number of local Jewish community studies from 38 then to 266 as of 2020 .

What can we conclude from this table? The social scientific study of Jewry has become more diverse, encompassing many more professionals, representing many more disciplines, and is no longer male-dominated. In all ways, this diversity produces a broader field providing a more expansive way to understand, analyze, and account for the behaviors of Jews. While the field has participated in professional meetings of sociologists, anthropologists, and religious scholars, among others, it is fair to say that the greatest response and, I might add, participation has been at the annual meeting of AJS. The reason for this is likely to be that social science provides an empirical way of understanding the behavior of Jews in the twenty-first century, which may offer illuminating contrasts to the behavior of Jews, for example, in the first century.

\section{Grounds for Optimism Versus Pessimism in Viewing the Future of American Jewry}

One way to distinguish between the optimist and the pessimist is as follows: "The pessimist sees the difficulty in every opportunity, and the optimist sees the opportunity in every difficulty." Of course, the original pessimistic outlook in Western civilization appears in the biblical book, Kohelet or Ecclesiastes, and is attributed traditionally to King Solomon in his old age, which begins, "Hevel havalim, hakol hevel," or "Vanity of vanities, all is vanity" (1:2).

Consider the following:

\footnotetext{
1 As we go to press, the Pew Research Center (2021) released its latest survey, Jewish Americans in 2020, and reported 7.5 million Jews in the USA. Some of the other statistics that I cite later from Pew 2013 may be updated by consulting Pew's American Jews in 2020 (Pew Research Center 2021).
} 
Drawing optimistic or pessimistic conclusions about the prospects for the continuity of Jewish life may be as old as the Jewish people. Consider the informed observer of Jewish life, fortunate to still be alive toward the end of the first century after the destruction of the Second Temple and the elimination of political autonomy in ancient Israel. It would be expected that such an individual would be pessimistic and might spend time writing dirges about the suffering the Jews experienced. Such an individual might not have been able to imagine that the future would bring great religious scholarship in the creation of the Talmud in Babylonia; followed by the flowering of Jewish life in Western Europe, including the commentaries of Rashi and the writings of Maimonides; succeeded by the rise of Eastern European religious writings on the one hand and secular Zionism on the other; and most recently, the blossoming of Jewish culture and scholarship in North America and the newly reborn Jewish homeland in Israel. Thus, it might be fair to state, that Jewish life is in a perennial state of deconstruction and reconstruction. Consequently, the pessimists focus on the former and the optimists on the latter. (Dashefsky and Sheskin 2015:6)

Ponder the following examples of optimistic versus pessimistic polarities among American Jews:

1. Antisemitism is increasing, but Jews are the most warmly regarded US religious group.

2. Interfaith marriage continues yet stabilizes, but a majority of children are receiving a Jewish upbringing.

3. The religious "nones" (or those with no formal religious connection) are growing, but the great majority of them feel proud to be Jewish.

4. Geographic mobility and residential dispersion continue to spread, but new means of cyber-connections are growing.

Let us look at the evidence.

\section{Antisemitism is Increasing, but Jews are the Most Warmly Regarded US Religious Group}

Since 1964, the ADL has tracked antisemitic attitudes in the US, using the same 11-item scale (Smith and Schapiro 2019:119), when it reported, as we noted earlier, that $29 \%$ of Americans were considered to be antisemitic. In the past four decades "the index has ranged from 12\% (in 1998, 2009, and 2013) to a high of $17 \%$ (in 2002) with no clear trend" (Smith and Schapiro 2019:115). The most recent ADL estimate, as noted above, was $11 \%$ (ADL 2020). Thus, over the past half-century, the proportion of Americans who harbor antisemitic attitudes has declined by about 
Table 3 Jews viewed warmly

\begin{tabular}{ll}
\hline & Mean thermometer rating \\
\hline Jews & 63 \\
Catholics & 60 \\
Mainline Protestants & 60 \\
Buddhists & 57 \\
Evangelical Christians & 56 \\
Hindus & 55 \\
Mormons & 51 \\
Atheists & 49 \\
Muslims & 49 \\
\hline
\end{tabular}

Note: Respondents who declined to rate a group are not shown

Source: Survey conducted Feb. 4-19, 2019, among U.S. adults. "What Americans Know About Religion"

Source: Pew Research Center (2013)

three-fifths. Furthermore, "a frequently-used survey measure, the feeling thermometer, asks respondents to indicate how warm or cold they feel toward people or groups on a scale from 0 to 100 . The ratings of Jews have increased over time from a low of 57 degrees in 1975 to a high of 71 degrees in 2016" (Smith and Schapiro 2019:115).

More recently, in 2019, the Pew Research Center reported, as shown in Table 3, that: "Of all US religious groups, Jews received the warmest scores with a mean thermometer rating of 63, followed by Catholics and Mainline Protestants, each with a score of about 60" (Pew Research Center 2019:60). ${ }^{2}$

In addition, Dashefsky and Sheskin (2020:xi) reported:

In contrast, nearly a century ago, Bogardus (1928) asked about 2000 Americans to rate 40 different ethnic groups on a "social distance scale," from "7: would exclude from my country" to "1: to close kinship by marriage." The most favored groups were British, Americans, and Canadians, followed by northern Europeans, then southern and eastern Europeans. Jews were in the middle; and at the bottom of the social distance scale were people of color. The dramatic difference between 2019 and 1928 in the position of Jews helps us to understand why intermarriage for Jews has increased (see Phillips 2018).

Do these findings pose a difficulty or an opportunity?

\footnotetext{
${ }^{2}$ This difference is much greater than the difference between 63 and 60 degrees. Jews are about $2 \%$ of American adults, while 15\% are Mainline Protestant and 22\% are Catholic. Assuming that just about all who belong to a religious group feel warmly toward their own group, the percentage of non-Jews who feel warmly toward Jews is much higher than the percentage of non-Catholics who feel warmly toward Catholics and non-Mainline Protestants who feel warmly toward Mainline Protestants.
} 
Table 4 Upbringing of children in interfaith marriage

\begin{tabular}{ll}
\hline Raised Jewish by religion & $28 \%$ \\
Raised Jewish in some other way & $42 \%$ \\
Not raised Jewish in any way & $30 \%$ \\
\hline
\end{tabular}

Source: Pew Research Center (2021)

\section{Interfaith ${ }^{3}$ Marriage Continues Yet Stabilizes, but a Majority of Children are Receiving a Jewish Upbringing}

According to the most recent national probability study of American Jews, the Pew Research Center study (2013), the individual Jewish interfaith marriage rate was $17 \%$ for those married prior to 1970 in marriages that were still intact in 2013. For those marriages formed in the 1970s, the rate was slightly less than four in ten (36-39\%). Beginning in 1995, the rate hovered just below six in ten (57\%); but in the two decades following until the publication of the Pew Research Center report in 2013, the rate stabilized at six in ten (59-60\%). Thus, interfaith marriage has increased dramatically in the past half-century but has stabilized in the recent past.

In regard to the rearing of children in interfaith marriage, based on the Pew Research Center study (2021) as reported in Table 4, 70\% of children are receiving a Jewish upbringing, although only a minority of them are raised Jewish by religion.

Do these findings pose a difficulty or an opportunity?

\section{The Religious “Nones” Are Growing, but the Great Majority of Them Feel Proud to Be Jewish}

The religious "nones," in the case of American Jews, are those individuals who are Jewish, but claim no religious identification (Orthodox, Conservative, Reform, Reconstructing, etc.). They represent slightly less than one-third (30\%) of the population (Pew Research Center 2013:48). The growth of the religious "nones" is also similarly apparent among the larger Christian population, and this growth is more apparent among those under age 30, both Jewish and non-Jewish.

On the other hand, while $94 \%$ of American Jews state they are "proud to be Jewish," among the Jewish "nones," that proportion slips somewhat to 83\%, as shown in Table 5; and most of them (53\%) have a strong sense of belonging to the Jewish people (Pew Research Center 2013:52).

Do these findings pose a difficulty or an opportunity?

\footnotetext{
3 The terms mixed marriage, intermarriage, and interfaith marriage are presumably interchangeable. I have chosen to use "interfaith marriage" because "intermarriage" is often used pejoratively (as in "the threat of intermarriage," or "intermarriage is the new Holocaust"). "Mixed marriage" is another possibility, but it also has negative connotations historically from the literature on "miscegenation." Keren McGinity (2014) has found "interfaith" to be the least offensive term to such couples themselves.
} 
Table 5 Jewish pride

\begin{tabular}{|c|c|}
\hline & $\begin{array}{l}\text { Are proud to } \\
\text { be Jewish } \%\end{array}$ \\
\hline NET Jewish & 94 \\
\hline Jews by religion & 97 \\
\hline Jews of no religion & 83 \\
\hline Men & 94 \\
\hline Women & 94 \\
\hline Ages 18-49 & 94 \\
\hline $18-29$ & 96 \\
\hline $30-49$ & 94 \\
\hline Ages 50+ & 94 \\
\hline $50-64$ & 93 \\
\hline $65+$ & 94 \\
\hline Married & 93 \\
\hline Spouse Jewish & 97 \\
\hline Spouse not Jewish & 89 \\
\hline Not married & 95 \\
\hline Orthodox & 98 \\
\hline Ultra-Orthodox & 100 \\
\hline Modern-Orthodox & 93 \\
\hline Conservative & 98 \\
\hline Reform & 96 \\
\hline No denomination & 87 \\
\hline
\end{tabular}

Source: Pew Research Center (2013) Survey of U.S. Jews, Feb. 20-June 13, 2012. Q.Ea-c, p. 52

\section{Geographic Mobility and Residential Dispersion Continue to Spread, but New Means of Cyber-Connections Are Growing}

Geographic mobility can be viewed as the movement of people from one region of the USA to another. Between 1980 and 2019, the percentage of Jews in the Northeast declined by nearly one-quarter (from $57 \%$ to $44 \%$ ). While the proportion of Jews in the Midwest remained stable (12\% to $11 \%$ ), the proportion of Jews in the South increased by more than one-third (16\% to $22 \%$ ) and in the West by more than one-half (15\% to 23\%) (Sheskin and Dashefsky 2020:162). Note that, during these four decades, interfaith marriage rates increased from about four in ten $(42 \%)$ to nearly six in ten $(58 \%)$. In part, this may reflect the disruption of social and communal ties associated with such moves. This is particularly apparent in the West, which socializes Jews into a more religiously lax surrounding culture (Dashefsky and Phillips 2022).

A similar pattern exists in regard to residential dispersion in metropolitan areas. Goldstein and Goldstein (1996) posit that Jewish marriage markets have been weakened by dramatic population shifts. Communities that have experienced 
rapid growth are less Jewishly cohesive (Groeneman and Smith 2009; Rebhun 1995), so newcomers might have trouble finding the local Jewish marriage market. Consider Baltimore, which is a stable community that shows little population change from 1999 to 2010 . The interfaith marriage rate remained relatively stable over time, increasing from $17 \%$ to $20 \%$. The interfaith marriage rate in Chicago, another community with a relatively stable Jewish population, increased in that same period by a small percentage, from $30 \%$ to $33 \%$. The New York metropolitan Jewish population also increased slightly, and the interfaith marriage rate remained stable at 22\% (Phillips 2015).

By contrast in Atlanta, a Jewish boom-town, interfaith marriage increased from $37 \%$ in 1996 to $50 \%$ in 2006 . In Washington, DC, a community that has long experienced geographic mobility, the interfaith marriage rate increased from $29 \%$ in 1983 to $41 \%$ in 2003. Comparing Baltimore and Atlanta illustrates the impact of Jewish residential concentration. Both communities are about the same size, but the interfaith marriage rate in Atlanta is more than twice that in Baltimore. In addition to having experienced a rapid Jewish population increase, the Jewish population in Atlanta is also far more geographically dispersed than in Baltimore, where Jews are concentrated in the inner ring suburbs of Northwest Baltimore (Phillips 2015).

Despite the social disruptions associated with geographic mobility and residential dispersion, consider some of the following responses to the current pandemic, e.g., zooming prayer services, which can now include a global rather than just a local audience. In addition, Jewish virtual study can bring together more individuals from more locations to participate in learning opportunities than just those who can attend in-person. Furthermore, the internet has empowered individuals to find various Jewish study sites, e.g., "My Jewish Learning" or "Sefaria."

Following is a list of sites that one naïve surfer (a graduate student in sociology with no experience in the Jewish community) found:

- https://www.alephbeta.org/

- https://www.chabad.org/

- https://www.jewfaq.org/

- https://www.jewishvirtuallibrary.org/

- https://www.myjewishlearning.com/

- https://www.ou.org/

- https://www.reconstructingjudaism.org/

- https://reformjudaism.org/

- https://www.sefaria.org/

- https://torah.org/

- https://uscj.org/

- https://18doors.org/

Whether these new cyber formats will endure at the end of the pandemic remains to be seen, but do these cyber developments represent a problematic difficulty or an opportunity?

In concluding this section, I cannot predict how the tensions noted in these four statements will be resolved, but more optimistic outcomes are possible if the 
leadership of the major institutional and organizational entities within the community address these polarities based on where American Jews find themselves, rather than where the leaders would like them to be. Remember the words of the early-twentieth-century American sociologists, W. I. and D. S. Thomas, who defined the self-fulfilling prophecy thus: "If [people] define situations as real, they are real in their consequences" (1929:572). As I suggested above, Jewish life is always deconstructing and reconstructing. We may mourn what we have lost, but we must rejoice in what we possess. As David Brooks (2021) concluded in a recent column, "it is better to face the challenges of dynamism than the challenges of stasis" (The New York Times, February 12: A23).

\section{Recommendations for Future Research in the Social Scientific Study of US Jewry}

As I noted earlier, when I was still an untenured assistant professor, Marshall Sklare invited me, in 1975, as the coauthor of the recently published book, Ethnic Identification among American Jews (with H. M. Shapiro 1974/1993), to present a paper at Brandeis University. The result was published as "Theory, Method, and Social Policy in Ethnicity: Developmental Trends in the Study of Jews" (Dashefsky 1981). In that paper, I referred to the historical development and social context of the sociological study of American Jews that had been reviewed by Sklare (1974), Mayer (1973), Rosenthal (1971), and Lipset (1955). I noted that there was not one theoretical framework or methodology that united the field. Rather, I suggested that there were four different approaches: sociohistorical, demographic, social organizational, and social psychological. "Nevertheless, there is one recurrent theme that permeates much of the literature, and it is the attempt to explain the persistence of Jewish group survival and the continuity of Jewish identity" (1981:196).

The three themes in the article's title suggest a basis for recommendations to advance the social scientific study of US Jewry: theory, method, and social policy. Following are six recommendations, which have been useful guides in my scholarly career:

1. Build empirical research on a theoretical foundation.

2. Precede empirical research with sociohistorical analysis.

3. Emphasize multivariate analysis in quantitative analysis.

4. Parallel quantitative with qualitative research to provide a mixed-methods approach.

5. Expand comparative research across different communities and countries.

6. Sharpen policy recommendations by bringing preliminary observations to the stakeholders for comment.

Here are illustrations of these six recommendations from research to which I have contributed over the past half-century. 


\section{Build Empirical Research on a Theoretical Foundation}

Reports on Jewish interfaith marriage are cited frequently both online and in the press. Rarely do they ever delve into a theoretical understanding of the phenomenon. According to the Dutch demographer, Kalmijn (1998), there are three social forces that predict in-marriage versus out-marriage: (1) constraints of the marriage market, (2) preferences of individuals for certain characteristics in a spouse, and (3) the influence of the social group of which they are a member.

As Dashefsky and Phillips (2022) have demonstrated, based on national probability samples of American Jews and supplemented by qualitative analysis, the larger size of the Jewish population in a locality (a constraint of the marriage market) is associated with in-marriage. On the other hand, communities with a rapidly increasing Jewish population (e.g., Atlanta) have higher levels of interfaith marriage than more stable communities (e.g., Baltimore).

The second social force affecting in-marriage/out-marriage is preferences, including especially education and social distance. Dashefsky and Phillips (2022) pointed out that, both for the Jewish and non-Jewish minorities, educational homogamy (marriage within the same educational level) is associated with interfaith marriage. In addition, they noted that the social distance (the degree of closeness that one group feels toward members of a different ethnic or racial group) between Jews and non-Jews has narrowed greatly over the past century. In fact, the Pew Research Center (2019), as noted earlier, in its most recent survey found that Jews were regarded most warmly of all religious groups by a representative sample of all Americans.

The third factor noted by Kalmijn was the influence of social groups, or "third parties." Despite the limits of the marriage market for Jews as constrained by their small numbers as well as by their being a preferred group in American society, Phillips $(2013,2018)$ found that Jews were twice as likely to in-marry compared with Asians and five times as likely to in-marry as Hispanics. The likely explanation for this finding is arguably third-party influences, which promote group identification. The interpersonal influences through Jewish socialization experiences, including formal and informal Jewish education, may be more important in influencing Jewish marriage patterns. Consequently, the insights derived from a theoretical formulation of marriage patterns suggest that in-marriage for Jews in American society is higher than might be expected for such a small minority group.

\section{Precede Empirical Research with Sociohistorical Analysis}

In the "Foreword" to Jewish Choices (Lazerwitz et al. 1998), Andrew Greeley, the distinguished sociologist of religion and noted fiction author, wrote from a sociohistorical understanding of the role of religious denominations in American society and culture as follows:

This outsider has always been more optimistic that Judaism would survive in this country than many rabbis have been. Jewish Choices confirms that expec- 
tation. Judaism does survive and will survive as a denominational religion, both in its external relations and in its internal structure.

I must leave it to others to judge whether such denominationalism is good or bad. It seems to me, however, that it is inevitable. (Lazerwitz et al. 1998)

To examine the contemporary nature of Jewish denominationalism, one must understand the sociohistorical context of American society. As Lazerwitz et al. (1998:6) stated, "Given the importance of voluntarism and individualism within the American way of life, denominationalism has become a chief means of expressing one's religion here in America." This phenomenon of denominationalism was not apparent in many societies dominated by an established church, from which Jews emigrated to the USA. Given this context, Lazerwitz et al. (1998) provided a portrait of the sociohistorical evolution of Reform Judaism as the first denomination, followed by the counter-reformation of Orthodoxy and the resultant centrist denomination of Conservative Judaism, as embodiment of the dialectic: thesis, antithesis, and synthesis. Subsequently, the authors, relying on quantitative data from NJPS 1971 and NJPS 1990, reported on the following trends:

how individual American Jews relate, or fail to relate, to the three major Jewish denominations; how individual American Jews express themselves religiously within a denominational framework; and how they combine their denominational orientations with their involvements both in their local Jewish communities and with the community-at-large. (Lazerwitz et al. 1998:11)

\section{Thus, understanding the sociohistorical evolution of American Jewish denomi- nationalism paved the way for an empirical examination of the major branches of American Judaism.}

\section{Emphasize Multivariate Analysis in Quantitative Analysis}

In the original edition of Ethnic Identification Among American Jews, Dashefsky and Shapiro (1974:vi) quoted Mortimer Ostow: "The process by which Jews transmit their values and their commitment to group cohesion from generation to generation is poorly understood. However, the fact of this transmission cannot be denied." The authors of this monograph go on to empirically analyze the factors involved in the transmission of Jewish identification from generation to generation through multivariate analysis.

Drawing on a sample of 302 cases in St. Paul, MN, with a $63 \%$ response rate, the authors relied on regression analysis to present a picture of the shaping of Jewish identification for a younger generation of men, age 22-29, and their fathers. Three socialization factors together accounted for $28 \%$ of the variance in the younger generation: family (18\%), peers $(6 \%)$, and Jewish education (4\%). Thus, multivariate analysis revealed that the family was a three times more powerful influence than peers and four and one-half times more powerful than Jewish education in shaping Jewish group identification. When combining prior socialization factors with contemporary social ( or "structural") integration factors, the authors were able to account for $40 \%$ of the variance: "...five socialization variables account for 
14 percent of the variance, while the three [social integration or] structural variables explain 26\% of the variance in Jewish identification" (Dashefsky and Shapiro 1974:79).

For the older generation, the socialization variables accounted for $26 \%$ of the variance, with family accounting for $20 \%$ and peers for $6 \%$. Note that Jewish education was not a significant factor among the older men. When socialization factors and contemporary social ("structural") integration effects were modeled, $35 \%$ of the variance was explained, with three socialization factors accounting for $12 \%$ of the variance and the one social integration or "structural" variable, $23 \%$ of the variance. The differences between the generations suggests that Jewish group identification among the younger (mostly third) generation was more dependent on a wider variety of factors, whereas the older (mostly second) generation was likely more immersed in the totality of communal life.

The finding of generational differences revealed that the shaping of Jewish identification is dynamic. While some factors spanned both generations, e.g., the family, Jewish education was only statistically significant in the younger generation. In fact, the authors demonstrated that Jewish education produced a "mild but lasting independent effect" (Dashefsky and Shapiro, 2nd edition 1993:xvi) on Jewish identification.

Finally, this multivariate analysis inspired Alena Janet Strauss (1979) to produce a master's thesis replicating this study, with the powerful addition of including both young women and men in her Toronto sample. Her results for the males were similar to the original study. In regard to the females in the sample, Strauss found that the socialization experience of "activities with parents" was most important, whereas for males, "father's religiosity" was most important.

Thus, through multivariate quantitative analysis, the authors were able to enhance the understanding of the transmission of Jewish group identification and illustrate differences between two generations, thereby addressing the challenge posed by Ostow at the outset of their book.

\section{Parallel Quantitative with Qualitative Research to Provide a Mixed-Methods Approach}

Earlier mention was made of Andrew Greeley, the late distinguished sociologist, priest and novelist, who was cited in Lazerwitz et al. (1998). He also stated (1998:xvii), "It is axiomatic in this country where religious pluralism and voluntarism flourish, that religions organize themselves into denominational structures." Such an understanding inspired Dashefsky, Sheskin, and Winter (2020) to build on Greeley's assertion that denominationalism is inevitable in the USA. The implication of this assertion for American Jews is that it opens up multiple options to them in the pluralistic communities and identities that they inhabit.

To explore these options, Dashefsky, Sheskin, and Winter constructed a two-bytwo table around the key questions confronting American Jews: "Will one choose Jewish (communally oriented) or Western (individually oriented) models as Cultural Guidelines in one's life?" and "Will one emphasize Jewish religiosity (Judaism) or 
Jewish ethnicity (Jewishness, or Yiddishkeit) as a Structural Focus of one's Jewish involvement?" The result is a fourfold set of responses: (a) "Classical" Reform, a newer Westernized individualistic form of Judaism; (b) "Classical" Orthodoxy, a non-Western form of Judaism; (c) "Classical" Zionism, a Jewish communal secularity; or (d) "Just Jewish" Secularism, sometimes oriented to secular politics. Alternative modes that incorporate elements of more than one of these are possible. One of these alternatives, Conservative Judaism, which seeks to take a middle ground on both questions, also is examined. (Reconstructing Judaism, Traditional Judaism, and trans-denominational choices represent important new directions, but due to their smaller shares of the population at this time, they were not examined in great detail.)

The authors rely first on a sociohistorical review of the transformations of Jewish identity in the evolution of Jewish civilization, and a similar approach to the changes in American Jewish culture. They then provide a geographic, demographic, and religious profile of American Jews, which paves the way for laying out the schema of American Jewish options.

Having explained the various options available to American Jews, based on their sociohistorical review and supplemented by survey data, they utilized institutional histories and sociological studies including participant observation, in-house surveys, and national probability survey results as well as the Century 21 dataset (which includes over 27,000 cases from 27 Jewish communities that have completed studies of their Jewish populations since 2000) to examine in detail the variety of Jewish options.

\section{Expand Comparative Research Across Different Communities and Countries}

In a comparative study of US emigrants, Americans Abroad (Dashefsky et al. [1992] 2020:72), the authors addressed three questions: "1. What accounts for the motivations of migrants to move? 2. What are the sources of the adjustment problems the migrants experience? 3. What explains whether migrants remain or return?" This work was distinctive in that it examined all three factors in the emigration process: motivations, adjustments, and return or reverse migration. Ideally, researchers might have desired to construct one instrument to investigate these phenomena in multiple countries, but such an approach was beyond their means. Alternatively, they utilized multiple datasets from two countries, Australia and Israel, that were compatible. Utilizing a social psychological approach and relying both on demographic and quantitative survey analyses as well as qualitative analysis, they addressed the three questions noted above.

Relying on a two-by-two table, they arrayed the vertical axis on the "locus of concern" in emigration ("self" or "other") and the horizontal axis of "goals of migration" ("expressive" or "instrumental" goals). The authors concluded that, in regard to motivation, the primary factors for emigration to Australia and Israel at the time of their data collection (the 1970s) were "self-expressive," including the following: "adventure/travel," "alienation," and "religio-ethnic identity and self-fulfillment." In regard to the question of adjustments, the authors found that the focus in the $2 \times 2$ table rotated to "self-instrumental" factors, which dealt with "work," "housing," and 
the "daily standard of living." Turning to the third question examining the crosspressures of "remain vs. return," the authors reported that the focus in the $2 \times 2$ table rotated to "others-expressive" factors, surrounding "marriage," "family reunification and harmony," and "education of children." Thus, the reliance on a comparative approach, drawing on data from respondents in both Australia and Israel, provided a more complete model of the migration cycle.

Finally, the authors utilized path analysis to account for "staying-leaving" decisions. They found that a series of demographic and background factors showed direct effects on the decision. In addition, they reported that these factors related to "contact with veteran settlers" and "satisfaction with various areas of life," which in turn influenced "identification with the host society" and led to the strongest factor in "staying-leaving," namely, "confidence of remaining."

\section{Sharpen Policy Recommendations by Bringing Preliminary Observations to the Stakeholders for Comment}

In Charitable Choices, Dashefsky and Lazerwitz (2009) tell the story of how the cofounder of the big box store, The Home Depot, was introduced to making a charitable choice:

Bernie Marcus was just a young boy the first time he donated nickels to help plant trees in Israel. "That's what my mother taught me, that you have to give back," says the seventy-four-year-old cofounder and retired CEO of The Home Depot. "In fact, I couldn't understand why I was doing it. This was my ice cream money that I was giving away. But she said, 'You have to help people who are less fortunate; this is what we do.' It's called tzedakah in Hebrew" (Wurst 2003:42).

The authors relied on a social psychological approach and drew on both quantitative and qualitative data to examine the motivations for charitable giving. Based on their analysis, they concluded:

Overall, age, family income, Jewish education, denominational preference, synagogue membership and attendance, more involvement in Jewish primary groups, more home religious practices, and a positive orientation toward Israel formed the set of normative factors that increased both giving to and activity in Jewish charitable fundraising. For many Jews, activity in Jewish fundraising, in its turn, led to activity in non-Jewish (general community fundraising).

(Dashefsky and Lazerwitz 2009:28)

Their findings give credence to the story reported above by the noted entrepreneur and philanthropist. In addition, the qualitative analysis also supported the importance of Jewish socialization experiences influencing charitable giving. On this basis, the authors suggested the following measures in interpersonal fundraising:

a four-fold approach at the micro level of reaching individuals in their local communities, called the NESS Program, from the Hebrew word meaning miracle. (If 
one can put all the pieces together and be successful, one will have achieved a miracle.) (Dashefsky and Lazerwitz 2009:32)

The four elements that were based on their research were as follows:

1. Name-identification, i.e., identifying potential individual giving;

2. Evaluation, i.e., determining each prospect's interests and passions;

3. Socialization, i.e., educating the donor through a socialization process;

4. Solicitations, e.g., following implementation of the above steps, solicitation may be undertaken.

When this fourfold approach was presented to a group of fundraisers, they were remarkably in agreement as to the four steps. Nevertheless, they stressed that a fifth step was necessary to be effective fundraisers. They suggested that the NESS model needed a fifth letter, "S," which stood for "Stewardship," i.e., sustaining the relationship with the donor before and after solicitation. Therefore, this experience of bringing preliminary findings to some stakeholders for feedback further sharpened the policy recommendations derived from the research.

\section{Recommendations for the Future of ASSJ}

Based on my experience with ASSJ over five decades, two recommendations stand out:

\section{Networking with other professional associations:}

Over the years, a number of ASSJ members have organized sessions at other professional meetings and have attracted colleagues who otherwise would not be associated with ASSJ. One recent example was a first-ever "Preconference on Antisemitism," organized at the annual meeting of the American Sociological Association by Dashefsky and Goldberg (2019), on the topic, "After Charlottesville and Pittsburgh: Theoretical, Empirical, Comparative, Pedagogical, and Policy Implications of Sociology of Antisemitism." About 35 attended the session, the largest number since the session in 1970 at which ASSJ was created!

2. Increasing membership of graduate students and junior faculty:

Many veteran members of ASSJ are keenly aware of the need to expand the number of younger colleagues in the Association. Toward that end, I have proposed to the officers and Board of ASSJ to create a fund that would pay for the first year of membership for graduate students as well as junior and contingent faculty; and I have offered my personal contribution to cover that expense over the next 3 years. 


\section{Conclusion: Personal Tribute to My Family}

Most of you do not know that my mama-loshon, my mother tongue, is Yiddish because my parents (z'l) as Jewish educators decided that I would eventually learn Hebrew but not Yiddish unless they spoke to me in that language. In fact, my father and mother were also my first teachers of Hebrew. I recall that, in first grade, I had a lot of trouble with the letter tet; and the teacher, my exasperated mother, sent me to the principal, who was my father! For their giving me the keys to the Hebrew and Yiddish languages, I am very grateful.

Also, I want to express a tribute of loving thanks to my immediate family, to my children, Alisa, Michael, and Laura, and to my granddaughters Ally, Liv, and Elle, for being a constant source of pride and joy. They have appreciated my comments on historical events and holiday observances, but usually chimed in with: "Here we go again!"

Last, but surely not least, I want to publicly express my profound thanks to Sandy, my wife and life partner, for her abundant love and support, across more than five decades of our marriage. She has made my life one of incomparable joy and beauty. It has been especially meaningful for us to share our overlapping personal and professional journeys together. The Hebrew inscription that appears on our wedding rings, Dodi nafshi ya'ir, "My beloved awakens my soul," is as true today as it was on the day of our marriage.

Permit me to finish with a quote from the Talmud: "Talmidei hakhamim marbim shalom ba'olam," "Scholars increase peace in the world." Therefore, I end with this praise: To scholars and to peace!

\section{References}

Anti-Defamation League (ADL). 2020. Antisemitism in the US. Retrieved October 30, 2020. https:// www.adl.org/what-we-do/anti-semitism/antisemitism-in-the-us.

American Jewish Committee (AJC). 2020. The state of antisemitism in America, 2020: Comparing American Jews and the general public. Retrieved November 12, 2020. https://www.ajc.org/Antis emitismReport2020/Comparing-American-Jews-and-General-Public.

Berman Jewish DataBank. n.d. U.S. national: National studies of U.S. Jews. Retrieved February 23, 2021 https://www.jewishdatabank.org/databank/search-results?category=U.S.\%20National.

Bogardus, Emory S. 1928. Immigration and race attitudes. Lexington, MA: D.C. Heath \& Company.

Boxer, Matthew. 2020. Personal communication.

Brooks, David. 2021. The coming technology boom. The New York Times, February 12: A23.

Dashefsky, Arnold. 1981. Theory, method and social policy in ethnicity: Developmental trends in the study of Jews. Ethnicity 8: 196-205.

Dashefsky, Arnold, and Chad Alan Goldberg. 2019. Preconference on the sociology of Antisemitism. American Sociological Association. "After Charlottesville and Pittsburgh: Theoretical, Empirical, Comparative, Pedagogical, and Policy Implications of Sociology of Antisemitism." Organized by AJYB, ASSJ, and Berman Jewish DataBank. August 9, New York.

Dashefsky, Arnold, and Bernard Lazerwitz. 2009. Charitable choices: Philanthropic decisions of donors in the American Jewish community. Lanham, MD: Lexington Books.

Dashefsky, Arnold, and Bruce A. Phillips. 2022. Interfaith marriage. Cham: Springer.

Dashefsky, Arnold, and Howard M. Shapiro. [1974] 1993. Ethnic identification among American Jews. Lanham, MD: UPA. 
Dashefsky, Arnold, and Ira M. Sheskin. 2015. Are you 'Pewish'? Multiple assessments of the landmark Pew survey. In American Jewish year book 2014, vol. 114, ed. Arnold Dashefsky and Ira M. Sheskin, 3-8. Cham: Springer.

Dashefsky, Arnold, and Ira M. Sheskin. 2020. Preface. In American Jewish year book 2019, vol. 119, ed. Arnold Dashefsky and Ira M. Sheskin. Cham: Springer.

Dashefsky, Arnold, and Ira M. Sheskin. 2021. Preface. In American Jewish year book 2020, vol. 120, ed. Arnold Dashefsky and Ira M. Sheskin. Cham: Springer.

Dashefsky, Arnold, Ira M. Sheskin, and (the late) J. A. Winter. 2022. Jewish options. Lanham, MD: Rowman and Littlefield.

Dashefsky, Arnold, and Karen A. Woodrow-Lafield. 2020. Americans abroad: A comparative study of emigrants from the United States, second edition. Cham: Springer (originally coauthored by Arnold Dashefsky, Jan DeAmicis, Bernard Lazerwitz, and Ephraim Tabory 1992, Plenum Press).

Friedman, Norman L. 1986. Conception and birth of the Association for the Sociological Study of Jewry: A case study in associational formation. Ethnic Forum 6: 98-111.

Goldstein, Sidney, and Alice Goldstein. 1996. Jews on the move: Implications for Jewish identity. Albany, NY: State University of New York Press.

Groeneman, S., and T.W. Smith. 2009. Moving: The impact of geographic mobility on the Jewish community. New York, NY: Jewish Federations of North America.

Kalmijn, Matthijs. 1998. Intermarriage and homogamy: Causes, patterns, trends. Annual Review of Sociology 24: 395-421.

Kramer, Judith R., and Seymour Leventman. 1961. Children of the gilded ghetto: A candid closeup of three generations of American Jews. New Haven, CT: Yale University Press.

Lazerwitz, Bernard, J.A. Winter, Arnold Dashefsky, and Ephraim Tabory. 1998. Jewish choices: American Jewish denominationalism. Albany, NY: SUNY Press.

Lipset, S.M. 1955. Jewish sociologists and sociologists of the Jews. Jewish Social Studies 17: 177-178.

Martindale, Don. 1960. The nature and types of sociological theory. London: Routledge.

Mayer, E. 1973. Jewish orthodoxy in America: Towards the sociology of a residual category. Jewish Journal of Sociology 15: 151-165.

McGinity, Keren R. 2014. Marrying out: Jewish men, intermarriage \& fatherhood. Bloomington, IN: Indiana University Press.

Pew Research Center. 2013. A portrait of Jewish Americans. Washington, D.C.: Pew Research Center.

Pew Research Center. 2019. What Americans know about religion. Washington, DC: Pew Research Center.

Pew Research. 2021. Jewish Americans in 2020. Washington, DC: Pew Research Center.

Phillips, Bruce A. 2013. New demographic perspectives on studying intermarriage in the United States. Contemporary Jewry 33 (1-2): 103-119.

Phillips, Bruce A. 2015. The geography of Jewish intermarriage in five US urban areas. In The changing world religion map: Sacred places, identities, practices and politics, ed. S.D. Brunn, 3249-3281. Dordrecht: Springer.

Phillips, Bruce A. 2018. Intermarriage in the twenty-first century: New perspectives. In American Jewish year book 2017, vol. 117, ed. Arnold Dashefsky and Ira M. Sheskin, 31-119. Cham: Springer.

Rebhun, Uzi. 1995. Geographic mobility and religioethnic identification: Three Jewish communities in the United States. Journal for the Scientific Study of Religion 34 (4): 485-498.

Rose, Arnold M., and Caroline B. Rose, eds. 1965. Minority problems: A textbook of readings in intergroup relations. New York: Harper \& Row.

Rosenthal, E. 1971. The current status of Jewish social research. Midstream 17: 58-62.

Sheskin, Ira M., and Arnold Dashefsky. 2020. United States Jewish population, 2019. In American Jewish year book 2019, vol. 119, ed. Arnold Dashefsky and Ira M. Sheskin, 135-231. Cham: Springer.

Sklare, Marshall, ed. 1974. The Jew in American society. New York: Behrman House.

Smith, Tom W., and Benjamin Schapiro. 2019. Antisemitism in contemporary America. In American Jewish year book 2018, vol. 118, ed. Arnold Dashefsky and Ira M. Sheskin, 113-161. Cham: Springer.

Strauss, Alena J. 1979. Social psychological determinants of Jewish identification among Canadians in their twenties. Master's thesis, University of Toronto.

Thomas, William I., and Dorothy S. Thomas. 1929. The child in America. New York: Knopf.

Waxman, Chaim I. 2019. Family and identity: Marshall Sklare, the social scientific study of America's Jews, and Jewish communal policy. Contemporary Jewry 39: 379-406.

Wurst, N.H. 2003. Giving back. Southwest Airline Spirit 12 (8): 42-45. 
Publisher's Note Springer Nature remains neutral with regard to jurisdictional claims in published maps and institutional affiliations.

Arnold Dashefsky is the Doris and Simon Konover Chair of Judaic Studies and Professor of Sociology Emeritus and was the founding Director of the Center for Judaic Studies and Contemporary Jewish Life at the University of Connecticut. Currently, he is Senior Academic Consultant to the Berman Jewish DataBank and Director Emeritus, as well as editor (with Ira Sheskin) of the American Jewish Year Book. He has co-authored, co-edited, and edited 15 books and numerous articles and papers on Jewish identity, family, ethnicity, emigration, and interfaith marriage. Arnie was a founding member, secretary-treasurer, vice president, and president of the Association for the Social Scientific Study of Jewry and served as editor of its journal, Contemporary Jewry. He is the recipient of the Berman Award (2012) and the Sklare Award (2020), both from ASSJ.

\section{Authors and Affiliations}

\section{Arnold Dashefsky ${ }^{1}$}

Arnold Dashefsky

arnold.dashefsky@uconn.edu

1 Department of Sociology, Center for Judaic Studies and Contemporary Jewish Life, University of Connecticut, Storrs, CT, USA 